\begin{abstract}
"Mircea cel Batran" Naval Academy Scientific Bulletin, Volume XX - 2017 - Issue 1 The journal is indexed in: PROQUEST / DOAJ / Crossref / EBSCOhost / INDEX COPERNICUS / DRJI / OAJI / JOURNAL INDEX / I2OR / SCIENCE LIBRARY INDEX / Google Scholar / Academic Keys/ ROAD Open Access I Academic Resources / Scientific Indexing Services / SCIPIO / JIFACTOR
\end{abstract}

\title{
MID SEMESTER ASSESSMENT OF STUDENT'S KNOWLEDGE - AN EXAMPLE RELATED TO THERMODYNAMICS
}

\author{
Elena GOGU ${ }^{1}$ \\ Andrei PREDA ${ }^{2}$ \\ Ionela TiICU ${ }^{3}$ \\ ${ }^{1}$ Ph.D, "Gheorghe Duca" High School, Constanta, \\ ${ }^{2} \mathrm{Ph} . \mathrm{D}$, Constanta Maritime University, \\ ${ }^{3} \mathrm{Ph} . \mathrm{D}$, Constanta Maritime University,ionela.ticu@yahoo.com
}

\begin{abstract}
This paper deals with the issue of how it is treated the partial assessment of part time students enrolled in Faculty of Naval Electromechanics, in Constanta maritime University, related with the discipline Thermodynamics 1. This discipline is in the curricula of future marine engineers, in their second year of study, the second semester. This form of verification is planned in the seventh week of the semester and represent $20 \%$ of the final grade of the student. The partial assessment of this type of students is compulsory. Students are informed about the examination date, the number of lessons to be evaluated and the percentage of the partial assessment from the final grade, since the beginning of the semester, through timetable discipline. In this paper it is discussed the mid semester assessment for the above mentioned discipline and the conclusions of lecturers, after their evaluation.
\end{abstract}

Keywords: Thermodynamics, part time students, assessment

\section{INTRODUCTION}

Part time education is an integrated form of higher education, featured by flexible instruction, education through synthesis courses and applicative training. These activities are periodically and compactly scheduled, by face to face meetings between students and lecturers, within the academic framework.

Part time education training means are specific for this form of education.

The time specific for this education form is the same as the one of full time education program. The structure of its curricula is also the same as the one of full time education program.

The training process is characterized by:

- Replacing teaching hours (course) through self-study activities.

- Knowledge communication through specific means such as printed material, $C D$ or the e-learning platform of the University.

Face to face meetings between the students and their lecturers are planned weekly, in order to take place the compulsory activities mentioned in the curricula: seminars, labs, projects, practical training, etc.

Part time education is an attractive form of education, since the student is able to choose where to study, when to study, the form of communication with its mates and lecturers, etc.

The teaching material for the part time students has to respect certain pattern, meaning that it should to be developed into units. Each unit should have formulating themes, specific objectives, scientific content, tests and results, comments and references.

Knowledge assessment system must include:

- Continuous assessment (formative), during the semester;
- Final assessment (examination, verification, colloquium), at the end of the semester.

Formative assessment has a share in the final grade. It takes place during the face to face activity or by the help of an eLearning platform. Students should be informed about the nature and purpose of formative assessments, by the lecturer, at the beginning of the semester.

The final evaluation is done after the same procedure applied to the students enrolled in full time education program.

For each discipline from the curricula are assigned coordinators, lecturers and tutors. These persons are listed on the website of the university in order to be easily identified by the students.

The discipline coordinator will manage the knowledge evaluation process, the final score, given by the two types of assessments, being the one which is recorded in the register of the discipline.

The discipline coordinator has the following responsibilities:

- coordinates the teaching team of its discipline

- develops test

- develops study materials

- assesses students through the two types of evaluation mentioned above

- ensures that part time students are gaining the same amount of information with the same quality as those enrolled in full time education together with lecturers conducting face-to-face activities

- provides on line support- through forums of communication available on the e-learning platform and offline support- by weekly 
meetings (consultations), individually or for group of students

- Activities planning.

The lecturer who conducts face to face applicative activities, mentioned to be compulsory in the curricula, is dealing with seminars, laboratories, practical work, projects, practical training.

Briefly, the tasks of the lecturer performing the face-to-face activities are:

Setting out the compulsory activities from the curricula, according to the schedule and in the same manner as for full time students

Provides on-line and off-line assistance individually and / or group of students

Provides information regarding the use of educational services available on the website of the discipline throughout the e-learning platform

Posts on the website of the e-learning platform the following materials:

Posts the results obtained by the students during the evaluations, results which are provided by the coordinator, etc.

Tutors guide students throughout the training period. Assistance is carried out individually or in groups, through direct meetings, correspondence, telephone, electronic mail, discussion forums organized on the virtual platform or through these combined forms. They inform students regarding top management decisions, opportunities, duties and rights.

This paper examines how the students enrolled in the form of part-time education, are tested for the discipline Thermodynamics I, during the formative evaluation, through a quiz which contains a set of nine questions. These questions are dealing with the first and second principles of thermodynamics

\section{CONTEXT OF STUDY}

The economic crises has a negative influence, registered in all fields of activity, including shipping, but the request of highly skilled specialists on board the ships has not been diminished, that is why maritime education institutions are still asked to provide education in the framework of exigency[1]. In Constanta Maritime University, the education of future marine engineers is offering means of achieving of theoretical, practical and design skills able to lead the future professional to a self-trust on board [2].

For future marine engineers, as for any future engineers, Thermodynamics is an essential discipline for a competent professional on board, due to the fact that it provides knowledge related to thermal and energy systems, based on the using and understanding of equation of state, property tables and charts [3].

There are many ways to approach the concept of engineering thermodynamics teaching and learning, since the subject is very generous, but in the same time we have to take into account the perception of students regarding this discipline, which see it to be only abstract theory with no connection with practical situations [4] [5].

In Constanta Maritime University, the course of Thermodynamics I is delivered to the students in their second year of study, and in the case in which they are enrolled in the Naval Electromechanical Faculty, during the second semester of the year.

Formative assessment of student for Thermodynamics I is planned, as the schedule of the discipline states, in the seventh week of the semester and represent $20 \%$ of the final grade of the student.

All the information regarding this mid semester assessment it is provided to the student through different channels: discipline coordinator, lecturer or tutor.

In the academic year 2015-2016, the formative assessment of the discipline Thermodynamics I was supported by $25 \%$ of all students enrolled, the remaining $75 \%$ being in voyage at sea. Formative evaluation consisted in solving of a short test (30 minutes) that reflects the degree of gaining the knowledge till the moment of the assessment. Formative assessment took place during the face to face meeting, at the end of the test being discussed the way of right solving of the quiz.

The results were communicated to students through the e-learning platform. The condition of passing this assessment is to answer to at least 4 questions.

\section{EXAMPLE OF ASSIGMENT FOR ENHANCEMENT OF STUDENT DEPTH OF KNOWLEDGE DURING THE SEMESTER}

In order to be identified the difficulties in understanding the concepts encountered by the students till the middle of the semester, the coordinator has developed a quiz, able to help students to exceed possible obstacles in gaining the needed competencies [6] [7] [8]. Under each question $(Q)$ it is given the right answer $(A)$.

Q1: Representation of the technical work in (p-v) 
"Mircea cel Batran" Naval Academy Scientific Bulletin, Volume XX - 2017 - Issue 1 The journal is indexed in: PROQUEST I DOAJ / Crossref / EBSCOhost / INDEX COPERNICUS / DRJI / OAJI / JOURNAL INDEX / I2OR / SCIENCE LIBRARY INDEX / Google Scholar / Academic Keys/ ROAD Open Access I Academic Resources / Scientific Indexing Services / SCIPIO / JIFACTOR

A1:

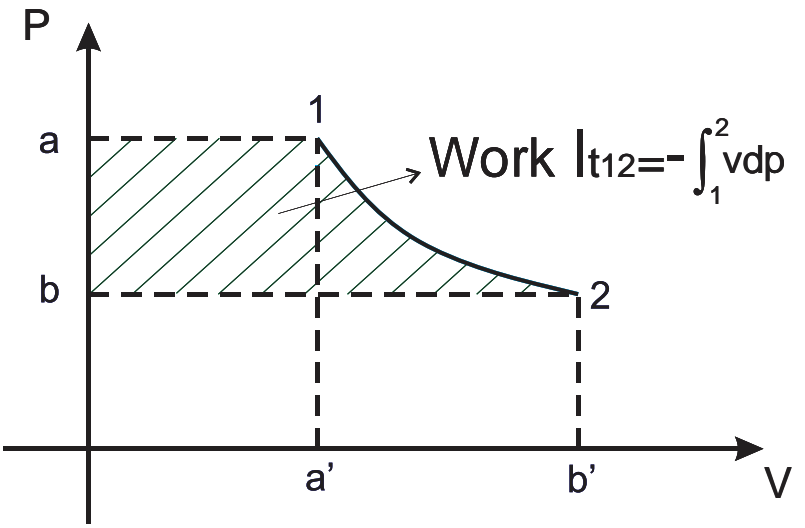

Q2: Which is the sign convention for the heat exchanged by a thermodynamic system during a process?

A2

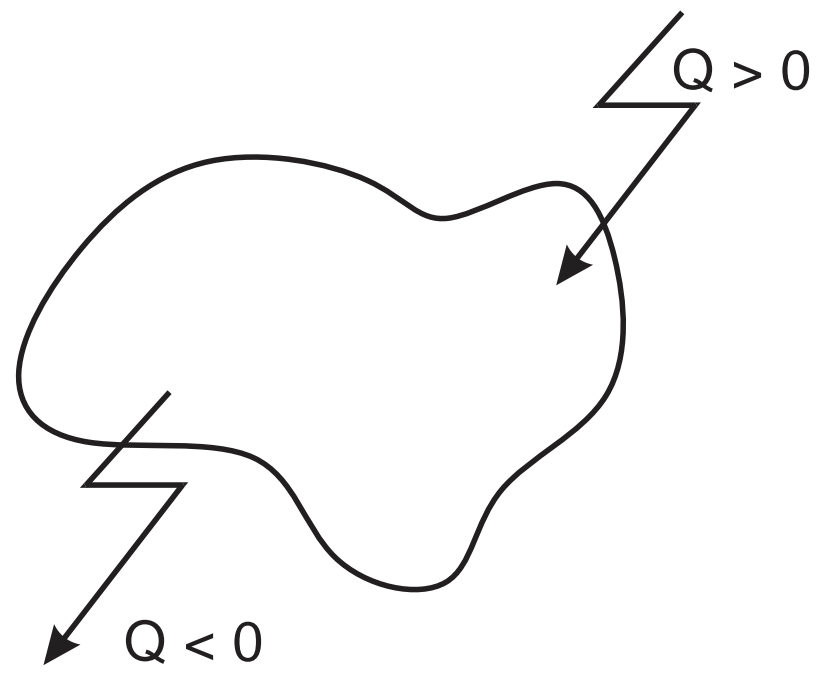

Q3: Which is the formula of enthalpy? Name the terms involved.

A3:

$$
H=U+p V \quad[J]
$$

Where:

$\mathrm{U}$ - internal energy;

$\mathrm{pV}$ - work of displacement

Q4: Which is the formula of work exchanged during an isochoric process?

A4:

$$
L_{12}=\int_{1}^{2} p d V=0 \quad[J]
$$

Q5: Find the formula of specific technical work during an isothermal process:

A5:

$$
l_{t 12}=\int_{1}^{2} v d p=R T \ln \frac{P_{2}}{P_{1}}
$$

DOI: 10.21279/1454-864X-17-I1-073

(c) 2017. This work is licensed under the Creative Commons Attribution-Noncommercial-Share Alike 4.0 License.
Q6: In the cylinder of a marine internal combustion engine, there is air at $t_{1}=550 \mathrm{C}$. After the isobaric burning of fuel, it is developed a quantity of gas which leads to the doubling the air volume. Find out the temperature at the end of burning, in Kelvin degrees.

A6: $1646 \mathrm{~K}$

Q7: Write the statements of the second law: A7:

1) No apparatus can operate in such a way that the only effect is to convert heat absorbed by a system completely into work done by the system.

2) It is not possible a process which consists solely in the transfer of heat from one temperature level to a higher one.

3) In an isolated system any transformation of energy into heat is irreversible.

Q8: Representation of an isochoric process in (T-S) diagram

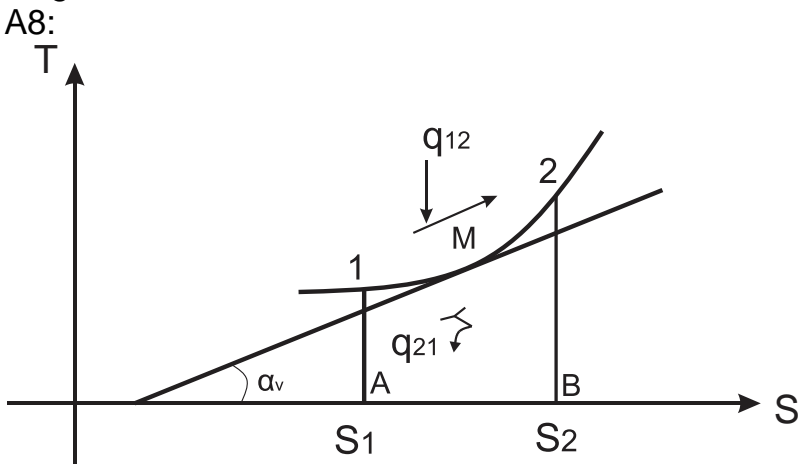

Q9:Which is the entropy variation in the engine room of a bulk carrier, knowing that the temperature in the room is $35 \mathrm{C}$ and the heat released to the environment by the equipment is 1 , $543 \mathrm{MJ}$.

A9: $5,01 \mathrm{~kJ} / \mathrm{K}$

\section{DISCUSSION ON THE OBTAINED RESULTS}

The results obtained by the students, for each question are as sein in Table 1. The number of students attempting the assessment of knowledge was 26.

Table 1. Overview of the results

\begin{tabular}{|l|l|l|}
\hline Question & Chapter & $\begin{array}{l}\text { No } \\
\text { correct } \\
\text { answers }\end{array}$ \\
\hline Q1 & First Law & 24 \\
\hline Q2 & First Law & 26 \\
\hline Q3 & First Law & 23 \\
\hline Q4 & First Law & 26 \\
\hline Q5 & First Law & 26 \\
\hline Q6 & First Law & 21 \\
\hline Q7 & Second Law & 19 \\
\hline
\end{tabular}




\section{"Mircea cel Batran" Naval Academy Scientific Bulletin, Volume XX - 2017 - Issue 1 The journal is indexed in: PROQUEST / DOAJ / Crossref / EBSCOhost / INDEX COPERNICUS / DRJI / OAJI / JOURNAL INDEX I I2OR / SCIENCE LIBRARY INDEX / Google Scholar / Academic Keys/ ROAD Open Access I Academic Resources / Scientific Indexing Services I SCIPIO I JIFACTOR}

\begin{tabular}{|l|l|l|}
\hline Q8 & Second Law & 19 \\
\hline Q9 & Second Law & 8 \\
\hline
\end{tabular}
students are more familiar with the first law of thermodynamics, which is explained by the fact that students understand easier the fact that when heat is introduced in a system, part of that form of energy is kept in the system and other part is leaving the system.

Students are already used with this issue from high school.

Students show difficulty in solving questions related to the second law, in comparison with the first law, since second law is, because of its specific concepts, more abstract and difficult to be connected with practical cases. Even the simple enunciation of the second law could not be solved by all students (Q7).

Demonstrations have not put students in difficulty, all of them being able to solve these points of the quiz (Q4, Q5).

Instead, the calculation question specific to the first law (Q6) indicates a low result in comparison with the theoretic ones from the same chapter (Q1-Q5). Same conclusion is available for the second law calculation question (Q9), in comparison with the theoretic questions related to the second law (Q7, Q8).

\section{Conclusions}

The results obtained for the analysed quiz showed that students are more familiar with the principle of thermodynamics dealing with enegy, meaning with the first law.

Theoretical issues are solved by the all the participants, while the calculations are solved by $88 \%$.

Second law is more abstract for the students. Even the simple enunciation of this law is not stated by all the participants. In fact, all the questions from the second law have lower rating that the ones specific to the first law.

In the same trend it is also the part of the quiz dealing with second law calculus. This question was solved by the lowest number of students. Only $31 \%$ solved this question. This question has the lowest score from the whole quiz.

Thoretical questions have been solved more easily than the ones requiring a calculation. The results indicate that the lecturer should allocate more time to the calculus issues, during the face to face meetings, on the elearnig platform or during additional classes, at the student requirement. Such a measure should be taken before the final examination, in order to help part time students to pass the final examination.

\section{Bibliography}

[1] MEMET, F., A guide for assessing vapour compression refrigeration systems for future marine engineers, Constanta Maritime University Annals, Vol.23, Year XVI, pp.61-66, 2015;

[2] MEMET, F., An experience in refrigeration calculation carried out by future marine engineers in CMU, Constanta Maritime University Annals, Vol.22, Year XV, pp.61-64, 2014;

[3] MEMET, F., Attempts for a better understanding of entropy by the students in CMU, Analele Universitatii "Eftimie Murgu" Resita, Anul XXII, Nr1, pp 285- 294, 2015;

[4] BAKER, D., EZEKOYE, O., SCHMIDT, P., JONES, C., LIU, M., ThermoNet: A web based learning resource for engineering thermodynamics, Proc of the American Society for Engineering Education Annual Conference \& Exposition, American Society for Engineering Education, pp 748-754, 2000;

[5] MEMET, F., Attemps for a better understanding of entropy by the students in CMU, Analele Universitatii "EFTIMIE MURGU" Resita, anul XXII, nr. 1, pp 285-294, 2015;

[6] CENGEL, Y., BOLES, M., Thermodynamics: An Engineering Approach, 8 edition, McGraw-Hill Education, pp 1024, 2014;

[7] MEMET, F., MITU, D.E., Termotehnica. Manualul Ofiterului Maritim, Ed. Nautica, pp 181, 2012;

[8] TUDOR, D., TUDOR, C., Termotehnica, Masini si Instalatii Termice Navale, Ed. AGIR, pp 358, 2002. 